czącej bezpośrednio kwestii bitwy oraz okoliczności pojedynku bizantyńsko-seldżuckiego pod Manzikertem, a także sytuacji Cesarstwa w XI wieku.

Dobór materiału źródłowego jest właściwy i wyczerpujący. Zwracam jednak uwagę na fakt pewnych, drobnych niekonsekwencji. Autor na ogół korzystał z wydań w językach oryginalnych, z pewnymi wyjątkami, co może być zrozumiałe. Dlaczego jednak nie jest nic wspomniane, że niektóre źródła funkcjonują (np. Psellos, Anna Komnena) w języku polskim? Natomiast w przypadku źródeł orientalnych autor korzystał z przekładów i opierał się z powodzeniem na tłumaczeniach angielskich (np. Ibn al-Atīr, Mateusz z Edessy) lub francuskich (np. Michał Syryjczyk). Pisownia niektórych terminów orientalnych (arabskich, tureckich) pozostawia nieco do życzenia (np. 112, p. 545). Tu można mnożyć takie przykłady (raz pisownia „dż”, potem wedle angielskiej wersji ,j”, zamiast przyjętej w polskiej nauce jednoznacznej formy „,̆’). Wykorzystanie tekstu Wilhelma z Tyru jest incydentalne, to jednak opieranie się na wydaniu z RHC HOc. I, nie jest już wskazane, gdyż istnieje daleko poprawniejsza wersja w edycji z 1985 roku.

\title{
Zdzisław Pentek
}

Nenad Vekarić, Vlastela grada Dubrovnika. Korijeni, struktura i razvoj dubrovačkog plemstva, Hrvatska akademija znanosti i umjetnosti. Zavod za povijesne znanosti u Dubrovniku, Posebna izdanja, knj. 17 sv. 1, Zagreb-Dubrovnik 2011, ss. 347.

Historycy chorwaccy od lat w swych badaniach poświęcają dużo uwagi dziejom dawnej Republiki Dubrownickiej, co owocuje znaczną liczbą publikacji. Szczególne znaczenie na tym polu ma aktywność kierowanego od 1987 r. przez prof. Nenada Vekaricia Instytutu Nauk Historycznych Chorwackiej Akademii Nauk w Dubrowniku (HAZU Zavod za povijesne znanosti u Dubrovniku). Ośrodek ten obok periodyku Anali oraz jego anglojęzycznej wersji Dubrovnik Annals wydaje w cyklu Monumenta Historica Ragusina materiały z przebogatych zasobów Państwowego Archiwum w Dubrowniku. Wielką wartość naukową mają również liczne monografie poświęcone różnorodnym aspektom życia dawnej Raguzy. Do tej ostatniej grupy należy też wydana w 2011 r. praca N. Vekaricia Vlastela grada Dubrovnika. Korijeni, struktura i razvoj dubrovačkog plemstva, która jest siedemnastą w serii Prilozi povjesti stanovništva Dubrovnika i okolice. Jednocześnie jest to pierwsza książka z zaprojektowanego przez autora cyklu czterech prac poświęconych dubrownickiej szlachcie (dwie następne ukazały się już w 2012 r.).

Zgodnie z podtytułem praca składa się z trzech rozdziałów. W pierwszym z nich Korijeni dubrovačkog nobiliteta, autor przedstawił złożony problem genezy dubrownickiej szlachty. Na wstępie N. Vekarić omówił fazy rozwoju aparatu władzy w mie- 
ście oraz przeanalizował strukturę miejskiej społeczności we wczesnym okresie. Autor słusznie zwrócił uwagę na paralelny rozwój instytucji zarządu miasta oraz szlachty jako grupy społecznej. Podkreślił kluczowe znaczenie zamknięcia się Wielkiej Rady w 1332 r. dla przekształcenia względnie otwartej grupy możnych (słowo nobiles autor bierze tu w cudzysłów) we właściwą szlachtę (nobiles), wyraźnie odgrodzoną od obywateli (cives) prawnym mechanizmem. Poważne wątpliwości budzi jednak ustalenie przez N. Vekaricia liczebności szlachty dubrownickiej w 1300 r. na 1675 osób (s. 19 oraz tablica 19 s. 145). Autor niestety nie pokazał przekonywująco w jaki sposób doszedł do tak precyzyjnego i jednocześnie zaskakującego rezultatu. Przy uwzględnieniu ustaleń St. Krivošicia, iż cała populacja Dubrownika sięgała 3500 osób, pozwala to na zdumiewające stwierdzenie, iż blisko połowę mieszkańców miasta w $1300 \mathrm{r}$. stanowiła szlachta. Wyrażona przez autora opinia, iż przed zamknięciem Wielkiej Rady za szlachtę można uważać wszystkich obywateli (cives) miasta jest trudna do przyjęcia z metodologicznego punktu widzenia. N. Vekarić słusznie natomiast podkreślił, mało dotychczas eksponowany, związek między zamknięciem Wielkiej Rady i krystalizacją stanu szlacheckiego a szybką ekspansją terytorialną Dubrownika w następnym stuleciu. Etapy tej ekspansji dość szczegółowo zostały przez niego omówione. Wówczas właśnie wypracowano zwyczaj, iż po uzyskaniu nowych ziem znacząca ich część była dzielona między mieszkańców miasta, przy czym zdecydowaną większość rozdzielali między siebie członkowie szlacheckiej elity. Autor podziela pogląd, wyrażony wcześniej m.in. przez Z. Janeković-Römer, iż wobec przewagi handlu relatywnie niewielkie (15-25 ha) posiadłości ziemskie należące do nobilów nie miały wielkiego znaczenia gospodarczego, jednak sam fakt posiadania ziemi był niezwykle ważny, jako manifestacja szlacheckiego statusu i bogactwa.

N. Vekarić przeprowadził następnie drobiazgową analizę zachowanych tradycji pochodzenia dubrownickich rodów szlacheckich. Jego spostrzeżenia często tu powtarzają, ale też systematyzują i porządkują ustalenia wcześniejszych uczonych (M. Medini, Z. Janeković-Römer, S. Ćošicia). Według N. Vekaricia aż dwadzieścia rodów wywodziło swe pochodzenie ze starożytnego Epidarum a siedem wiązać można z kolonizacją rzymską. Bardzo liczną grupę tworzyły też rody o korzeniach słowiańskich. Autor zauważył trafnie, iż główne kierunki z jakich według legend pochodzić mieli Dubrowniczanie (tj. Bośnia, Włochy, Zatoka Kotorska i Czarnogóra oraz Albania) zbiegają się z ustalonymi przez uczonych kierunkami migracji ludności do miasta, co potwierdza ich wiarygodność. Vekarić wskazał także na błędy kronikarzy i bardzo skrupulatnie wyliczył je w tabeli (tabela 8 s. 71-74). Nie zmienia to faktu (co zauważył sam autor!), iż z uwagi na rodzaj zachowanych przekazów ustalenia w tym względzie mogą mieć w znacznym stopniu tylko hipotetyczny charakter.

W końcu pierwszego rozdziału N. Vekarić zajął się złożonym i delikatnym problemem genezy Raguzy i koegzystencji elementu romańskiego i słowiańskiego, co bywało w przeszłości przedmiotem poważnych kontrowersji w historiografii. Autor akceptuje relatywnie nową tezę, opartą na znaleziskach archeologicznych, iż osadnictwo na miejscu dzisiejszego Dubrownika istniało jeszcze na długo przed zniszczeniem 
Epidaurum przez Słowian. Jego zdaniem, odrzucić można opowieści o przeniesieniu się mieszkańców tego antycznego miasta na pustą, skalistą wyspę. Wczesna populacja osady stanowiła prawdopodobnie konglomerat ludności romańskiej i iliryjskiej, do której - po ucieczce ze swego miasta - dołączyli uciekinierzy z Epidaurum. Jeśli chodzi o przebieg dalszych zmian etnicznych $\mathrm{N}$. Vekarić prezentuje znany model, nie odbiegający od prezentowanego wcześniej przez badaczy chorwackich. Okrążony od VII w. przez słowiański żywioł Dubrownik podlegał cichym, spontanicznym migracjom, które zmienialy etniczny obraz miasta (s. 82). W efekcie w XI - XIII w. ludność romańska i Słowianie żyli tutaj w symbiozie, jednak znaczenie elementu słowiańskiego stale rosło. Powołując się na dawne językoznawcze badania P. Skoka autor stwierdza, iż z czasem zapanował swoisty bilingwizm: słowiańskim językiem posługiwano się w domu, zaś romański dominował w administracji. N. Vekarić zwrócił uwagę na kontrowersje wokół pochodzącego z 1253 r. układu Dubrownika z Michałem Asenem, który zawiera obszerną listę Dubrowniczan jako świadków. Przytoczył radykalnie odmienne oceny tego dokumentu, jaki swego czasu dali I. Mahnken oraz J. Lučić w kontekście jego znaczenia dla badania składu etnicznego elit dubrownickich. N. Vekarić odrzuca radykalne stanowiska obojga wcześniejszych badaczy na rzecz kompromisowego, acz enigmatycznego stwierdzenia, iż ...w Dubrowniku nie żyly dwa albo trzy narody - Romanie (dawni osiedleńcy $i$ nowo dosiedleni) i Stowianie, ale jeden Dubrowniczanie (Ragusei) (s. 88-89). Wsparciu opinii autora mają służyć obszerne tabele pokazujące paralelne formy nazwisk dubrownickich nobilów (schemat 2, tablica 13). Wobec kompromisowej postawy przyjętej wcześniej przez badacza zdecydowanie zbyt kategorycznie brzmi jednak jego późniejsze stwierdzenie, iż proces slawizacji zakończył się w XIV w., a konkretniej po roku 1348 r., kiedy w wyniku zarazy doszło do wielkiej migracji i nagłej zmiany obrazu etnicznego miasta. Autor nie przedstawił materiału źródłowego, który pozwalałby na wyciagnie tak jednoznacznego wniosku, a powołanie się w tej ważnej sprawie na popularne opracowanie I. Sindika wydaje się nieporozumieniem. Ze znakiem zapytania trzeba też przyjąć uznanie przez N. Vekaricia decyzji Wielkiej Rady z 1472 r. o wykluczeniu z dyskusji języka słowiańskiego jedynie za przejaw językowego konserwatyzmu (s. 89).

Drugi rozdział książki, zgodnie z tytułem (Struktura vlasteoskog staleža), poświęcony został strukturze warstwy szlacheckiej. N. Vekarić wyodrębnił i omówił tu szczegółowo wspólnoty, w jakich - jego zdaniem - funkcjonowała dubrownicka szlachta. Na poziomie więzów rodzinnych za najwęższą uznał rodzinę, czyli osoby powiązane pokrewieństwem, żyjące w jednym gospodarstwie. Autor przeanalizował strukturę rodziny szlacheckiej, czas wchodzenia w związki małżeńskie, dynamikę zmian $\mathrm{w}$ kręgu władzy związaną z wiekiem, rytmami poczęć, urodzin, małżeństw i śmierci. Chorwacki badacz pewną uwagę poświęcił też dzieciom szlachty poczętym poza związkami małżeńskimi. Drobiazgowo zestawione w tabelach informacje maja rzeczywiście wielką wartość. Szkoda jednak, iż koncentrując się na danych statystycznych, zwłaszcza z okresu nowożytnego, N. Vekarić wydaje się nie doceniać wagi dotychczasowych ustaleń dotyczących rodziny i dubrownickiego prawa rodzinnego, 
dokonanych np. przez Z. Janeković-Römer, a zwłaszcza V. Čučković, której fundamentalnych prac na ten temat $\mathrm{w}$ ogóle nie zauważył.

Wiele uwagi poświęca N. Vekarić pojęciu casata. Ma ono dla jego dalszych wywodów znaczenie fundamentalne. W przeciwieństwie do wcześniejszych badaczy, którzy uważali casata po prostu za odpowiednik rodu szlacheckiego opierającego się na tradycji pochodzenia od wspólnego przodka, według Vekaricia ...jest ona specyficznym typem złożonej miejskiej rodziny, która nie żyje wspólnie, jak w wiejskiej zadrudze, ale to rodzaj poszerzonej nuklearnej rodziny. Z powodu silnego odczuwania przynależności do rodziny poszczególni jej członkowie wciąż jeszcze nie sq całkiem niezależni ale funkcjonuja jako rodowy ,klan”(s. 129). Zauważając, iż tak zdefiniowane pojęcie wciąż jest dość mgliste autor podaje dalej badawczq definicję casata jako wspólnoty rodzinnej rodziców z dziećmi, gdy najwyżej jedno z tych dzieci jest już w małżeństwie i ma własne dzieci (s. 131). Inaczej mówiąc pierwszy syn, który się ożeni kontynuuje casata rodziców natomiast przy ożenku każdego następnego syna tworzą się nowe casata. Na podstawie tych definicji, przy pomocy szerzej nie opisanej metody genealogicznej $\mathrm{N}$. Vekarić ustala precyzyjnie liczbę szlacheckich casata w Dubrowniku dla zdumiewająco długiego okresu 700 lat (od 1150 do 1900 roku; np. w 1150 r. -18 casata, 1200 r. - 78, 1250 r. - 221, 1300 r. - 253 itp.). Autor przedstawia dalej graficznie zmiany liczebności casata, zestawienia nowoutworzonych oraz wymarłych itp. (tabele 30-31, wykresy 16-18). Ustalenia te służą też chorwackiemu badaczowi pomocą do szczegółowych wyliczeń droga genealogiczna populacji szlachty w latach 1300-1800 oraz ilości mieszkańców w jej gospodarstwach domowych w tym samym okresie. Nie wnikając w szczegółową metodykę skądinąd imponujących wyliczeń, nie sposób oprzeć się wrażeniu, iż autor za mało uwagi poświęcił prezentacji podstawy źródłowej oraz metody na jakiej oparł swe rachunki. Podważa to wiarygodność jego ustaleń nie tylko dla bardzo wczesnego okresu tj. lat 1150-1250 (dla których jak wiadomo brak zapisek notarialnych, bo te zaczynają się w 1278 r.) a w właściwie nawet do roku 1440 (kiedy to pojawia się księga serii Specchio, gdzie znajdujemy pierwsze wpisy młodzieży szlacheckiej wchodzącej do Wielkiej Rady). Należy zauważyć, iż oryginalna definicja casata, jaką podaje N. Vekarić oraz jego wyliczenie, iż w 1450 r. było ich w Dubrowniku aż 246, stoją w sprzeczności z ważnym w tej kwestii źródłem. Jak wiadomo, księga Specchio z 1440 r. zaczyna się od stwierdzenia, iż w Raguzie są 33 casate, po czym następuje alfabetyczny spis 33 rodów dubrownickich (vol. I, f. 1-1'Državni arhiv u Dubrovniku). Zatem sami Dubrowniczanie, przynajmniej do XV wieku, utożsamiali pojęcie casata z rodem. Szkoda, że autor nie próbował wyjaśnić przyczyny tej zasadniczej przecież rozbieżności.

Za najszerszą wspólnotę, w jakiej funkcjonowała dubrownicka szlachta uważa N. Vekarić klan. Jest to znów oryginalne spostrzeżenie, gdyż wcześniejsi badacze (przynajmniej w odniesieniu do średniowiecza i wczesnych czasów nowożytnych) w ogóle nie dostrzegali w Raguzie tego typu formacji. Częściowo thumaczy to przyjęta przez N. Vekaricia definicja, który klan uważa za nieformalne grupy casata, chcace osiagnąć wspólne cele polityczne. $Z$ tego też powodu nie pozostały po klanach ślady 
w zapisach i ich istnienie można wykazać tylko na podstawie pośrednich wskazówek (s. 159). Dalej autor streszcza koncepcję powstania trzech wielkich klanów (Juda - Gondola, Gozze, Bobalio) i ich udziału w życiu politycznym Dubrownika, którą sformułował i zaprezentował już w swej wcześniejszej pracy (Nevidljive pukotine. Dubrovački vlasteoski klanovi, Zagreb-Dubrovnik 2009). Tezy swe zilustrował licznymi tabelami drobiazgowo ilustrującymi pozycje klanowe casata, klanowe i międzyklanowe małżeństwa a także klanową przynależność rektorów (tabele 50-65).

W rozdziale trzecim (Dubrovačka vlastela kroz stolječa) autor dał szeroki przegląd różnorodnych aspektów funkcjonowania nobilów raguzańskich na tle życia miasta, przedstawionego w układzie chronologicznym od XII do XIX w. Choć N. Vekarić zajmuje się szeregiem zjawisk jak np. ekspansja terytorialna Dubrownika, rozwój przestrzeni miejskiej a nawet życie gospodarcze, wątkiem wiodącym rozdziału są zagadnienia demograficzne oraz procesy społeczne zachodzące wewnątrz warstwy szlacheckiej. Życie polityczne dubrownickich elit autor przeanalizował w świetle swej koncepcji budowy społeczności szlacheckiej w oparciu o casata i klany. Autor bardzo szczegółowo opisał ile z dubrownickich casata wygasło, a także, jakie i w jakich czasach się pojawiły. Drobiazgowo, w kilkudziesięciu tabelach i wykresach, wskazuje na przynależność klanową poszczególnych casata w okresie 500 lat - od 1300 do 1800 roku (tablice 66-78, wykresy 26-56). Wszystko to przedstawiono na tle kolejnych przełomowych wydarzeń i okresów w dziejach Raguzy: przejścia pod zwierzchnictwo Węgier (1358), „złotego wieku” handlu dubrownickiego na przełomie XV i XVI stulecia, kryzysu wieku XVII oraz katastrofalnego trzęsienia ziemi w 1667 r. a w końcu także walk o zachowanie neutralności w burzliwym XVIII w.

$\mathrm{Na}$ marginesie warto zauważyć, iż N. Vekarić zafascynowany statystyką casata i klanów robi milczące założenie, iż ich wpływ na politykę jest proporcjonalny do liczebności. Tymczasem w dotychczasowej, zgodnej opinii badaczy o politycznym znaczeniu rodu w Dubrowniku decydował raczej udział jego przedstawicieli w tzw. kręgu władzy - czyli w Radach i urzędach najbardziej wpływowych. Od połowy XV w. wiodącą rolę polityczną odgrywała w Raguzie nie Wielka Rada, ale Rada Zaproszonych, czyli Senat (D. Rheubottom, Z. Janeković-Römer) i może zaskakiwać, iż składu tego ciała tak skrupulatny autor nie poddał analizie.

Przedstawiony przez N. Vekaricia obraz stosunków wewnątrz warstwy szlacheckiej (przynajmniej dla XIII-XVI w.) wyraźnie odbiega od ustaleń wcześniejszych badaczy (M. Medini, I. Mahnken, B. Krekić, D. Rheubottom, Z. Janeković-Römer). Stwierdzali oni brak antagonizmów i większych napięć wśród dubrownickiej szlacheckiej elity. I. Mahnken analizująca środowisko nobilów dubrownickich w XIV w. podkreślała $n p$. iż nawet $\mathrm{w}$ dramatycznym momencie przejścia spod władzy weneckiej pod zwierzchnictwo węgierskie (1358) nie naruszona została ciągłość trendów w obsadzie stanowisk przez pewne rody. N. Vekarić zajmuje w tym względzie stanowisko dokładnie przeciwne, akcentując iż ....dramatyczne wydarzenia (...) zapaliby wojnę klanów, co spowodowało powstanie trzech opcji politycznych pro-weneckiej anty-weneckiej i pro-wegierskiej. Teza ta jest bardzo ciekawa i - o ile jest prawdziwa - ma ogromne znaczenie dla interpretacji dziejów Dubrownika w XIV w. Szkoda, 
że autor nie podbudował swego stanowiska źródłami i nie podjął dyskusji z opiniami przeciwnymi.

Analizy położenia szlachty dubrownickiej N. Vekarić nie kończy na dacie formalnej likwidacji Republiki Dubrownickiej w 1808 r. Poza drobiazgowym przedstawieniem strat poniesionych przez szlachtę oraz omówieniem demograficznych następstw wojny 1806 r. autor w oparciu zachowany spis ludności z 1817 r. przedstawił szczegółowe dane dotyczące płci szlachty, jej wieku a także rozmieszczenia według dzielnic (seksterii). Szczególnie fascynujący, nie tylko z perspektywy badacza ale także każdego miłośnika Dubrownika, jest końcowy fragment książki dotyczący wygasania szlacheckich rodów. Smutny ich koniec skłania do głębszej refleksji.

Dzieło N. Vekaricia zamyka trzynastostronicowe zakończenie oraz równie obszerne dwunastostronicowe streszczenie w języku angielskim, które umożliwia zapoznanie się z głównymi koncepcjami autora osobom nie znającym języka chorwackiego. Szkoda jednak, iż książka pozbawiona jest indeksów oraz brak w niej spisu źródeł i wykorzystanych opracowań, co należy już do powszechnych standardów w przypadku prac naukowych. Braku tego nie jest w stanie wypełnić imponująca forma książki, która pod względem estetycznym prezentuje się znakomicie. Twarda, znakomicie zaprojektowana oprawa przyciaga wzrok. Albumowy format i kredowy papier ułatwiły właściwe wyeksponowanie ponad siedemdziesięciu kolorowych wykresów i schematów i blisko dziewięćdziesięciu tablic, które są nie tylko ilustracją, ale istotnym składnikiem książki, będącym fundamentem wywodów autora.

Przedstawione wyżej wątpliwości, jak można zauważyć, odnoszą się przede wszystkim do tych partii książki, które dotyczą wcześniejszych dziejów Dubrownika. Wynika to z faktu, iż szczególnie mediewiści (pochodzący zarówno z Chorwacji, jak też spoza jej granic) wypracowali przez lata w swych pracach pewną wizję dziejów Raguzy, którą ustalenia N. Vekaricia w znacznym zakresie wprawdzie dopełniają i uściślają, ale też z którą w kilku istotnych punktach zdecydowanie kolidują. W tej sytuacji usprawiedliwione jest oczekiwanie, iż autor - wybitny i niezwykle ceniony badacz w zakresie demografii Dubrownika i jego regionu, zajmujący się dotychczas jednak przede wszystkimi dziejami nowszymi - podejmie polemikę z tymi poglądami i starannie, w oparciu o źródła, uzasadni swe nowatorskie koncepcje.

Szczegółowe uwagi nie umniejszają wartości książki, owocu benedyktyńskiej pracy autora, która w całości jest wielkim osiagnięciem i winna należeć do lektur obowiązkowych badacza zajmującego się nie tylko Republiką Dubrownicką ale dziejami Dalmacji w szerszym kontekście. Z pewnością będzie ona inspiracją do wielu dyskusji. $^{10}$

\section{Piotr Wróbel}

${ }^{10}$ Książka N. Vekaricia została entuzjastycznie zrecenzowana w czasopismach chorwackich przez Z. Pešordę oraz D. Vidovicia. Patrz: „Povijesni prilozi”, knj. 41, Zagreb 2011, s. 273-278; „,Folia onomastica Croatica", knj 20, Zagreb 2011, s. 262-266. 